\title{
Optimalisasi Laju Pengeringan Pada Alat Pengering Pakaian Yang Tidak Terpengaruh Waktu Dan Cuaca
}

\author{
Eko Edy Susanto ${ }^{1)}$,Febi Rahmadianto ${ }^{2)}$, Gerald Adityo Pohan ${ }^{3)}$ \\ Institut Teknologi nasional Malang \\ Fakultas Teknologi Industri \\ Jalan Karanglo Km.2, Malang \\ Email:rahmadianto15@gmail.com
}

\begin{abstract}
ABSTRAK
Penggunaan energi matahari unruk proses pengeringan pakaian tidak dapat dihandalkan ketika musim hujan tiba.Dimana proses pengeringan menggunakan energi matahari. Penggunaan energi matahari unruk proses pengeringan pakaian tidak dapat dihandalkan dikarenakan Perubahan cuaca yang tidak menentu karena itu dibuatlah "Alat Pengering Pakaian". Pembuatan alat pengering pakaian bertujuan untuk membantu proses pengeringan diwaktu cuaca tibak bagus.

Alat pengering pakaian mempunyai dua fungsi yang berbeda yaitu alat pemanas dan lemari pemanas atau pengering pakian. Alat pemanas terdapat Hand Blower dengan kecepatan 6 Speed dengan tujuan agar pengguna dapat menyesuaikan kecepatan udara panas yang ingin dialirkan ke lemari pemanas untuk mendapatkan hasil yang efisien untuk mengeringkan pakaian, dan menggunakan panas kompor sebagai sumber energi panas.

Temperature panas kompor $400{ }^{\circ} \mathrm{C}$ pada temperature ruangan $28^{\circ} \mathrm{C}$, Kemudian didapatkan Temperatur udara panas yang masuk ke lemari pemanas atau pengering $53-72{ }^{\circ} \mathrm{C}$ pada kecepatan putaran blower yang digunakan. Dan temperature udara panas Hasil pengujian dari alat pengering pakaian didapat efisiensi pada ruang pengering yang terbesar pada kecepatan putaran blower 3000 Rpm sebesar 6,42 \% dan efisiensi terkecil pada kecepatan putaran blower 9000 Rpm sebesar 0,38 .
\end{abstract}

Kata Kunci : Alat Pengering, Efisiensi, Sirkulasi Udara Panas, Kecepatan Putaran Blower, Gas LPG

\section{LATAR BELAKANG}

Penggunaan energi matahari unruk proses pengeringan pakaian tidak dapat dihandalkan ketika musim hujan tiba. Bagi pelaku bisnis seperti jasa laundri, dimana proses pengeringan menggunakan energi matahari, mengandung resiko cukup besar meskipun disisi lain memberikan keuntungan. Selain itu energi matahari tersedia melimpah dan juga gratis. Jumlah pakaian yang dapat dikeringkan dalam selang waktu tertentu dan juga tidak terbatas. Dengan demikian dibutuhkan peralatan pengering alternatif yagng mampu mengeringkan pakaian dengan energi lain saat matahari tidak dapat dihandalkan. (Kusbandono \& Untuk, 2015)

Pada saat ini jasa laundri merupakan bisnis yang menjanjikan, dimana sasaran utama dari pekerjaan maupun mahasiswa yang sibuk karena kegiatan dan tidak mempunyai waktu untuk mencuci. Dikota besar jasa laundri sangat banyak ditemui, apalagi disekitar Universitas yang ada d kota Malang. Persaingan jasa seperti itu membutuhkan inovasi dalam mencari pelanggan yang tetap. Perubahan cuaca seperti saat ini menjadi sedikit kerugian bagi jasa laundri yang membuat pakaian lama keringnya. Sedangkan waktu yang dibutuhkan untuk mengeringkan pakaian bagi jasa laundri adalah 2-3 hari untuksatu pelanggan. Ketergantungan manusia pada panas matahari dalam pemanfaatan untuk mengeringkan pakaian belum dapat ditinggalkan karena belum adanya alat dan teknologi yang mampu membuat manusia melepaskan ketergantungan terhadap panas matahari. (marpuah,2010)

Sehingga penulis menemukan inovasi alat yang dapat membantu proses pengeringan yang mampu melakukan proses pengeringan tanpa menggunakan sumber energy matahari. Sehingga tujuan membuat alat pengering pakaian yang dapat digunakan kapan saja.

\section{TINJAUAN PUSTAKA}

\section{Teori Pengeringan}

Pengeringan adalah operasi rumit yang meliputiperpindahan panas dan massa secara transien serta beberapa laju proses , seperti tranformasi fisik atau kimia,yang pada gilirannya dapat menyebabkan perubahan mutu hasil maupun meknisme perpindahan panas dan massa. Perubahan fisik yang mungkin terjadi meliputi pengkerutan, penggumpalan, kristalisasi, transisi gelas. Pada beberapa kasus, dapat terjadi reaksi kimia atau bio kimia yang diinginkan atau juga tidak diinginkan, yang menyebabkan perubahan warna tekstur, aroma atau sifat lain padatan yang dihasilkan. Sebagai contoh pada pembuatan katalis kondisi pengeringan dapat menyebabkan perbedaan nyata dalam aktivitas katalis tersebut melalui perubahan luas permukaan internalnya.(Kusbandono, 2015) 
Pengering terjadi melalui penguapan cairan dengan pemberian panas ke bahan umpan basahan. Sebagaimana disebut sebelumnya, panas dapatdisebabkan melalui koveksi (pengeringan langsung) konduksi pengeringantak langsung) radiasi atau secara volumetrik dengan menempatkan bahan basah tersebut dalam medan elektro maknetik gelombang mikro atau frekuensi radio. Lebih dari $85 \%$ mesin pengering industrial adalah jenis koveksi denan udara panas atau gas - gas pembakaran langsung sebagai media pengering mengakibatkan proses pelepasan air. Seluruh cara pengeringan, kecuali di elektrik (gelombang mikro atau frekuensi radio), menyediakan panas pada batas objek yang dikeringkan sehingga panas harus berdisfusi kedalam padatan dengancara konduksi. Cairan harus bergerak kebatas bahan sebelum diangkut keluar oleh gas pembawa

Pergerakan air didalam dalam padatan dapat terjadi melalui salah satu atau lebih dari mekanisme pindahan massa berikut

1. Difusi cairan, jika padatan basah berada pada suhu dibawah titik didih cairan tersebut.

2. Difusi uap jika cairan tersebut menguap dalam bahan.

3. Difusi knudsen jika pengeringanberlangsung pada suhu da tekanan sangat rendah, misalnya pada pengeringan beku.

4. Difusi permukaan (mungkin terjadi meskipun belum terbukti)

5. Beda tekanan hidrostatik, jika laju penguapan internal melampaui laju pergerakan uap melalui padatan kelingkungan sekitar.

6. Kombinasi dari mekanisme diatas

Perlu dicatat bahwa karenastruktur fisik padatan yang dikeringkan dapat berubah selama pengeringan, perpindahan air juga dpat berubah dengan bertambahnya waktu pengeringan.

\section{Klasifikasi Prinsip KerJa mesin Pengering}

Pengelompokan mesin pengering pakaian berdasarkan metode masuknya energi panas yang lebih bermanfaat kaena kemungkinan seseorang mencirikan beberapa gambaran kunci tiap - tiap kelompok mesin pengering

\section{Mesin pengeringan langsung}

Dikenal sebagai mesin pengeringan konveksi karena yang paling umum sampai saat ini sekitar $85 \%$ mesin pengering industrial diduga termasuk jenis ini terlepas dari efisien termalnya yang relative rendah akibat kesulitan untuk mengembalikan panas laten penguapan yang tersisa pada bagian pengeluaran mesin dalam pengertian efektivitas biaya. Udara panas yang diasilkan oleh pemanas langsung merupakan media pengeringan yang paling umum,meskipun untuk beberapa penerapan khusus, uap super panas akhir - akhir ini telah dibuktikan memberi efisiensi dan mutu lebih tinggi.

Gas hasil pembakaran dapat digunakan jika bahan tidak sensitive terhadap panas ataupun dipengaruhi oleh keberadaan hasil pembakaran. Pada mesin pengeringan langsung media pengering bersentuhan langsung dengan bahan yang dikeringkan, panas yang diperlukan untuk pengeringan disediakan melalui konveksi dan air yang menguap diangkut keluar oleh media pengering tersebut. Suhu gas pengeringan berkisaran $50^{\circ} \mathrm{C}$ hingga $400^{\circ} \mathrm{C}$ tergatung pada bahan yang dikeringkan. Udara denga kelembapan rendah mungkin diperlukan saat mengeringkan bahan sangat sensitive terhadap panas.

\section{Mesin Pengeringan Tak Langsung}

Meliputi penyediaan panas ke bahan yang dikeringkan tanpa bersentuhan langsung dengan media perpindahan panas,misalnya panas dipindah dari media panas (uap, gas panas, fluida panas, dll) kepadatan basah melalui konduksi. Karena tidak ada aliran gas yang melalui dinding padatan basah,perlu penerapan vakum atau pengaliran gas secara perlahan untuk mengangkut air yang diuapkan seingga ruang pengeringa tidak menjadi jenuh karena uap air. Suhu permukaan pindah panas dapat berkisar dari $-40^{\circ} \mathrm{C}$ (seperti pada pengeringan beku) sehingga $300^{\circ} \mathrm{C}$ pada kasus mesin pengering tak langsung yang dipanasi dengan hasil pembakaran langsung seperti limbah lumpur

\section{Jenis-Jenis Pengeringan Padatan}

\section{Pengering Nampang}

Sejauh ini pengeringan yang paling umu dihunakan untuk produk dengan jumlah yang tidak terlalu besar adalah pengeringan nampang secara curah, yeang terjadi dari satu atau beberapa kumpulan nampang yang ditempatkan pada ruang terinsulasi dimana udara panas di alirkan pada kipas dan kisi kisi pemandu yang dirancang sesuai keperluan. 


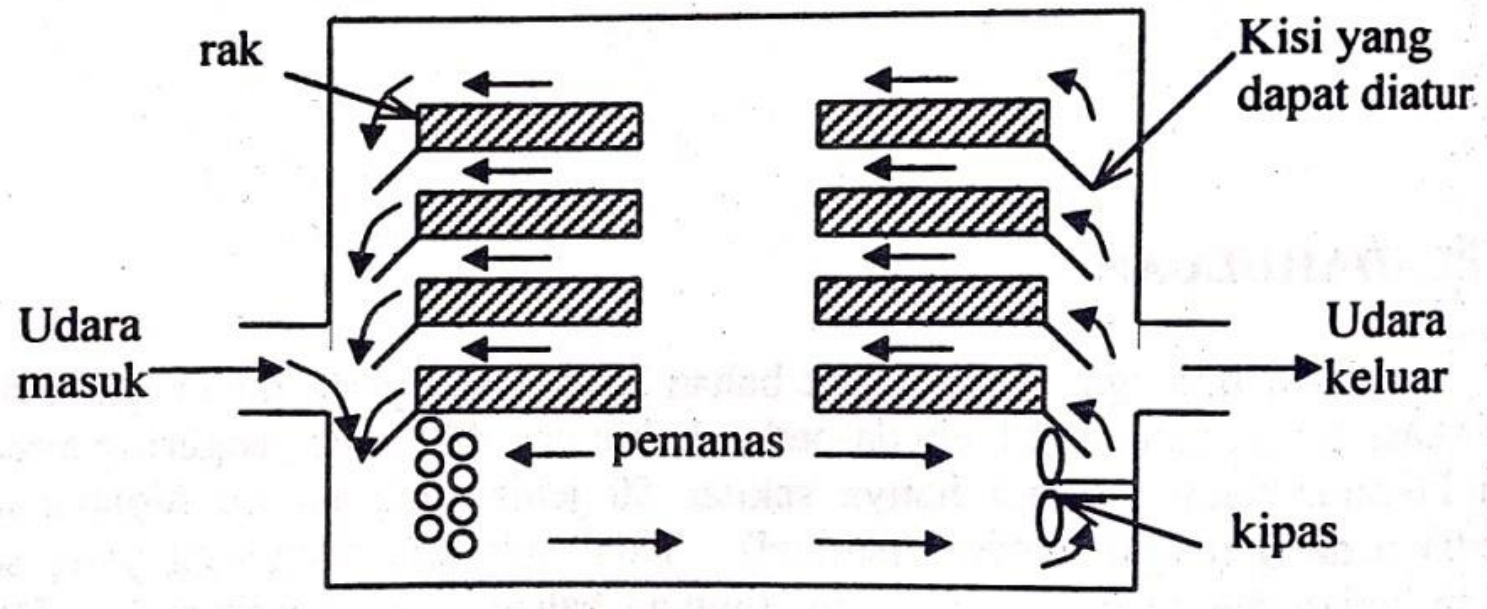

Fig. 1. Gambar. Pengering Nampang Jenis Curah (Sumber : Termodinamika Dasar, Mesin Konversi Energi)

\section{Pengering Rotari}

Pengering rotari bercascade adalah pengering kontak langsung yang beroperasi secara kontinyu dan terdiri atas angkang silinder yang berputar pelanserta biasanya dimiringkanbeberapa derajat dari bidang horizontal untuk membantu perpindahan umpan basah yang dimasukkan pada ujung atas drum.

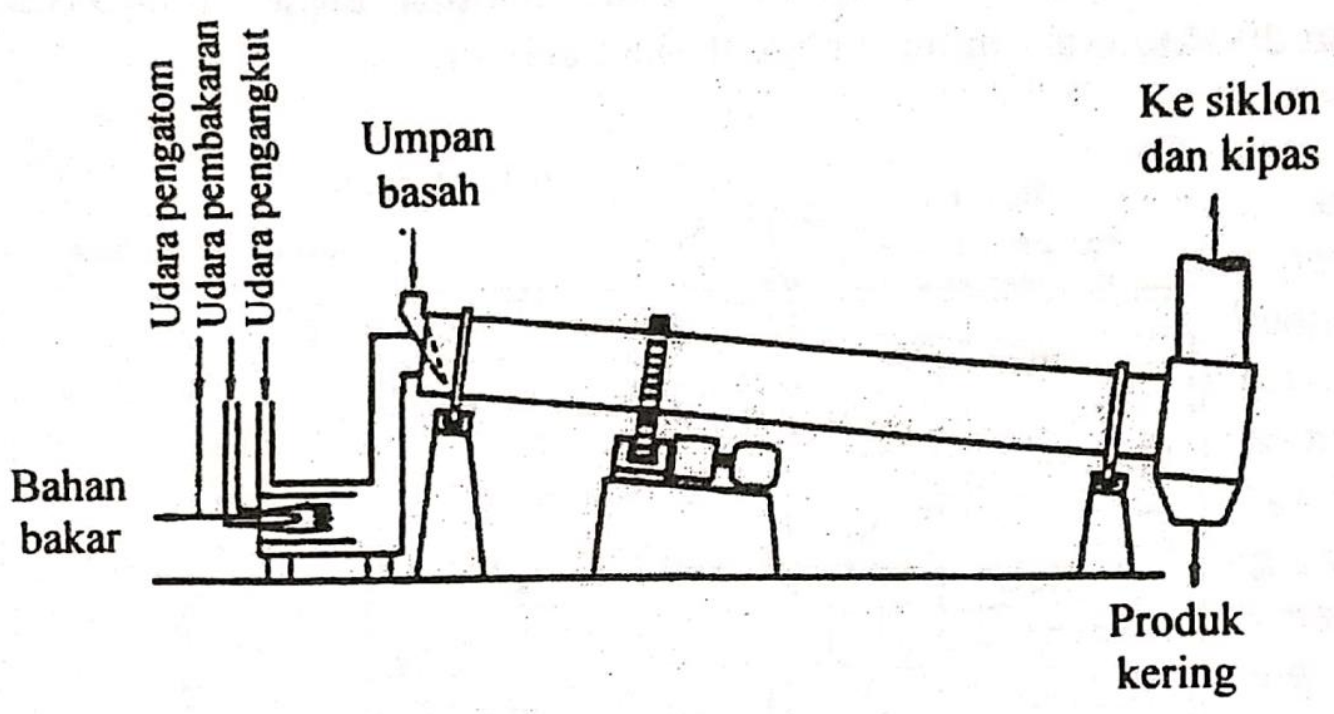

Fig. 2. Gambar. Pengering Rotari Bercascade

(Sumber : Termodinamika Dasar, Mesin Konversi Energi)

\section{Pengering BeKu}

Padatan yang sangat sensitif panas, seperti bahan bertenologi tertentu, bahan farmasi ata pangan dengan kandungan flavor tinggi, dapat di kering-bekukan dengan iaya yang sekurang-kurangnya setingkat lebih tinggi dari pengeringan semprot - merupakan oprasi pengeringan yang tidak murah. Disini pengeringan terjadi dibawah titi tripel cairan dengan menyublimkan air beku menjadi uap, yang emudian dkeluarkan dari ruang pengering dengan pompa vakum mekanis atau ejektor jet uap panas 


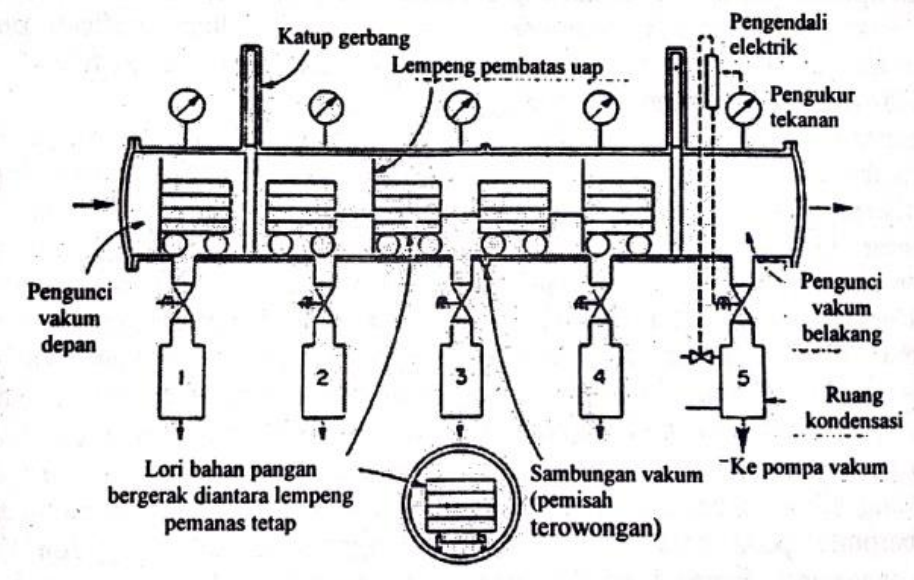

Fig. 3. Gambar. Pengering Beku Terowongan

(Sumber : Termodinamika Dasar, Mesin Konversi Energi)

\section{Pengeringan Vakum}

Untuk pengeringan padatan berbentuk butiran atau sluri, pengeringan vakum dengan berbagai rancangan mekanisme telah tersedia secara komersial. Pengering jenis ini lebih mahal dari pada pengeringan bertekanan atmosfer tetapi sesuai untuk bahan yang sensitif panas dan memerlukan pemulihan pelarut atau jika ada resiko kebakaran atau ledakan.percampuran bentuk kerucut tunggal atau ganda dapat diterapkan untuk pengeringan dengan pemanasan selimut dngan bejana dan pemvakuman.

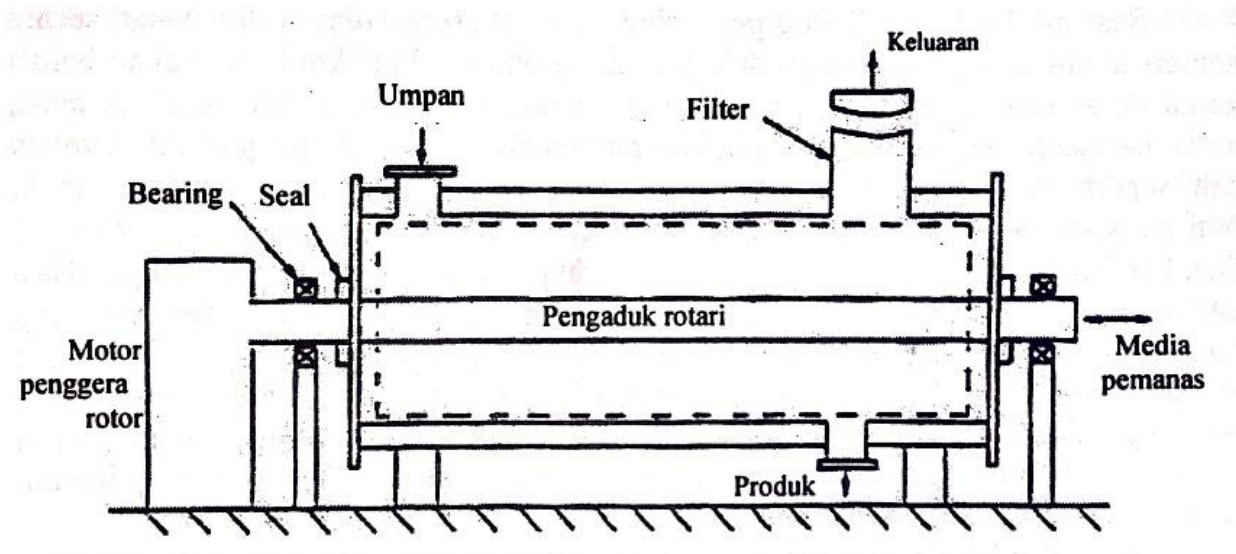

Fig. 4. Gambar. Pengering Vakum Jenis Pedal

(Sumber : Termodinamika Dasar, Mesin Konversi Energi)

\section{FAKTOR-FATOR YANG MEMPENGARUHI PENGERINGAN}

Pada pengeringan selalu dinginkan kecepatan pengeringan yang maksimal dan stabil. Karena diperlukan usaha untuk mempercepat perpindahan panas dan perpindahan massa. Dalam hal ini perpindahan massa adalah perpindahan air keluar dari bahan yang dikeringkan dalam proses pengeringan. Ada beberapa faktor yang perlu diperhatikan untuk memperoleh kecepatan pengeringan secara maksimum, antara lain :

1. Luas permukaan.

2. Temperatur.

3. Kecepatan Udara.

4. Tekanan Atm danVakum.

5. Kelembapan udara.

6. Waktu

Faktor yang perlu diperhatikan dalam perancangan mesin untuk memperoleh pengeringan maksimum adalah :

1. Luas Permukaan, dimana bahan yang dikeringkan mengalami proses pemerasan. Proses pemerasan ini akan mempercepat proses pengeringan. Hal ini disebabkan pemerasan kain akan mempermudah panas masuk ke rongga - rongga yang ada di kain akan mempermudah difusi dan menyebabkan penurunan berat. 
2. Suhu, dimana semakin besar perbedaan temperatur maka akan semakin cepat proses perpindahan panas berlangsung sehingga mengakibatkan proses penguapan semakin cepat. Atau semakin tinggi suhu udara pengeringan maka akan semakin besar pula.

3. Kecepatan dimana udara umumnya yang bergerak akan lebih banyak mengambil uap airdari permukaan bahan yang dikeringkan. Udara yang bergerak adalah udara yang mempunyai kecepatan gerakyang tinggi yang brguna untuk mengambil uap air dari permukaan bahan yang dikeringkan, sehingga dapat mrncrgah terjadinya uadara jenuh yang dapat memperlambat penghilangan air. Kecepatan udara umumnya udara yang bergerak akan lebih banyak membuat uap air dari permukaan bahan yang dikeringkan. Udara yang bergerak adalah udara yang mempunyai kecepatan gerak yang tinggi yang berguna untuk mengambil uap air dan menghilangkan uap air dari permukaan bahan yang dikeringkan, sehingga dapat mencegah terjadinya udara jenuh yang dapat memperlambat penghilangan air.

4. Kelembapan udara (RH) dimana semakin lembab udaranya didalam ruang pengering dan sekitarnya maka akan semakin lama proses pengerinannya, Begitu juga sebaliknya. Karena udara kering dapat mengabsorbsi dan menahan uap air. Setiap bahan mempunyai kelembapan masing - masing yaitu kelembapan pada suhu tertentu, dimana bahan tidak akan kehilangan air dari atmosfer atau tidak akan mengambil uap air dari atmosfer. Jika RH $<$ RH keseimbangan.

5. Waktu, dimana semakin lama waktu pengeringan (batas tertentu) makaakan semakin cepat proses pengeringan selesai. Dalam pengeringan ditetapkan konsep HTST (High Temperature Short Time) Short time dapat menekan biaya

6. Tekanan Atmosfer, pengeringan pada kondisi vakum menyebabkan pengeringan lebih cepat atau suhu yang digunakan untuk pengeringan suhu pengeringan daat lebihrendah. Suhu rendah dan ecepatan pengeringan yang tinggi diperlukan untuk mengeringkan bahan pangan.

7. Penguapan air, penguapan atau evaporasi merupakan penghilangan air dari bahan pangan yang dikeringkan sampai produk yan diperoleh produk kering yang stabil. Penguapan yang terjadi selaa proses pengeringantidak menghilangkan semua air yang terdapat dalam bahan pangan

8. LamaPengeringan, pengeringan dengan uhu tinggi dalam waktu yang pendek dapat lebuh menekan kerusakan bhan pangan dibandingkan yang lebih lama dan suhu yang lebih pendek.

\section{KALOR}

Kalor merupakan suatu energi yang mudah diterima dan mudah dilepaskan sehingga dapat temperatur zat tersebut menjadi naik dan turun. Sehingga energi kekal benda yang memiliki temperatur lebih tinggi akan melepaskan energi sebagai QL (kalor laten) dan benda yang memiliki temperatur lebih renda akan menerima energi sebesar QT (kalor sensible) dengan besar yang sama. Kalor jenis adalah sifat zat yang menunjukkan banyaknya kalor yang digunakan untuk menaikkan suhu zat bersama $1 \mathrm{Kg}$ sebesar $1^{\circ} \mathrm{C}$ atau $1 \mathrm{~K}$. Temperatur yang sama. Ternyata setiap benda akan menyerap energi alor dengan besar yang sama.

$$
\begin{aligned}
& \qquad \mathrm{Q}=\mathrm{m} \mathrm{C} \Delta \mathrm{T} \\
& \mathrm{Q}=\text { Kalor (Joule atau kalor) } \\
& \mathrm{C}=\text { kalor Jenis }(\text { Joule } / \mathrm{K} \text { atau } \mathrm{Kal} / \mathrm{C}) \\
& \Delta \mathrm{T}=\text { Perubahan Suhu }\left({ }^{\circ} \mathrm{K} \text { atau }{ }^{\circ} \mathrm{C}\right)
\end{aligned}
$$

Yaitu perpindahan perpindahan kalor dari benda bersuhu tinggi menuju ke benda bersuhu rendah.

\section{METODE}

Metode penelitian merupakan suatu cara ilmiah dalam perancangan penelitian untuk mendapatkan data atau informasi dengan tujuan tertentu. Metode yang digunakan dalam penelitian ini yaitu:

\section{Studi Literatur dan Lapangan}

Peneliti melakuakan studi atau kajian tentang judul dari jurnal penelitian tentang mesin pengering bagaimana cara kerja mesin pengering dan metode penelitian yang dipakai untuk menentukan sirkulasi udara panas pada mesin pengering pakaian dengan metode menggunakan blower. Pada studi literatur tersebut ada beberapa rumus dan teori yang dipakai dalam menentukan sirkulasi udara panas dan perhitungan kalor pada mesin pengering. Adapun rumus sebagai berikut Untuk menentukan kalor yang dihasilkan pada bahan bakar gas LPG.

\section{Metode Eksperimen}

Dengan pengujian langsung terhadap bahan/specimen yang akan diteliti tersebut. 


\section{PEMBAHASAN}

TABLE I. PENGAMBILAN PADA ALAT PEMANAS

\begin{tabular}{|c|c|c|c|c|}
\hline \multirow{2}{*}{$\begin{array}{l}\text { Kecepatan Putaran } \\
\text { Blower (Rpm) }\end{array}$} & \multirow{2}{*}{$\begin{array}{l}\text { Temperatur Panas } \\
\text { Kompor }\left({ }^{\circ} \mathrm{C}\right)\end{array}$} & \multirow{2}{*}{$\begin{array}{l}\text { Waktu } \\
\text { (menit) }\end{array}$} & \multicolumn{2}{|c|}{ Temperatur pada Alat Pemanas $\left({ }^{\circ} \mathrm{C}\right)$} \\
\hline & & & $T_{i n}$ & $T_{\text {out }}$ \\
\hline 3000 & 400 & 30 & 95 & 75 \\
\hline 3000 & 400 & 60 & 95 & 75 \\
\hline 3000 & 400 & 90 & 95 & 75 \\
\hline 3000 & 400 & 120 & 95 & 75 \\
\hline 3000 & 400 & 150 & 95 & 75 \\
\hline 3000 & 400 & 180 & 95 & 75 \\
\hline 3000 & 400 & 210 & 95 & 75 \\
\hline 5000 & 400 & 30 & 90 & 68 \\
\hline 5000 & 400 & 60 & 90 & 68 \\
\hline 5000 & 400 & 90 & 90 & 68 \\
\hline 5000 & 400 & 120 & 90 & 68 \\
\hline 5000 & 400 & 150 & 90 & 68 \\
\hline 5000 & 400 & 180 & 90 & 68 \\
\hline 5000 & 400 & 210 & 90 & 68 \\
\hline 7000 & 400 & 30 & 85 & 58 \\
\hline 7000 & 400 & 60 & 85 & 58 \\
\hline 7000 & 400 & 90 & 85 & 58 \\
\hline 7000 & 400 & 120 & 85 & 58 \\
\hline 7000 & 400 & 150 & 85 & 58 \\
\hline 7000 & 400 & 180 & 85 & 58 \\
\hline 7000 & 400 & 210 & 85 & 58 \\
\hline 9000 & 400 & 30 & 83 & 53 \\
\hline 9000 & 400 & 60 & 83 & 53 \\
\hline 9000 & 400 & 90 & 83 & 53 \\
\hline 9000 & 400 & 120 & 83 & 53 \\
\hline 9000 & 400 & 150 & 83 & 53 \\
\hline 9000 & 400 & 180 & 83 & 53 \\
\hline 9000 & 400 & 210 & 83 & 53 \\
\hline
\end{tabular}


Optimalisasi Laju Pengeringan Pada Alat Pengering Pakaian Yang Tidak Terpengaruh Waktu Dan Cuaca

TABle II. Pengambilan Data Pada Lemari Pemanas

\begin{tabular}{|c|c|c|c|c|c|c|c|}
\hline \multirow{4}{*}{$\begin{array}{c}\text { Kecepatan } \\
\text { Putaran Blower } \\
(\mathrm{Rpm})\end{array}$} & \multirow{4}{*}{$\begin{array}{c}\text { Waktu } \\
\text { (menit) }\end{array}$} & \multicolumn{6}{|c|}{ Temperatur Udara Panas Dalam Pipa $\left({ }^{\circ} \mathrm{C}\right)$} \\
\hline & & \multicolumn{4}{|c|}{ Masuk Ke Dalam Lemari $\left(T_{\text {out }}\right)$} & \multicolumn{2}{|c|}{ Temperatur didalam Lemari $\left({ }^{\circ} \mathrm{C}\right)$} \\
\hline & & \multicolumn{2}{|c|}{ Atas } & \multicolumn{2}{|c|}{ Bawah } & \multirow[b]{2}{*}{$T^{1}$} & \multirow[b]{2}{*}{$T^{2}$} \\
\hline & & $a$ & $a^{i}$ & $b$ & $b^{i}$ & & \\
\hline 3000 & 30 & 72 & 72 & 72 & 72 & 38 & 37 \\
\hline 3000 & 60 & 72 & 72 & 72 & 72 & 39 & 38 \\
\hline 3000 & 90 & 72 & 72 & 72 & 72 & 40 & 39 \\
\hline 3000 & 120 & 72 & 72 & 72 & 72 & 41 & 40 \\
\hline 3000 & 150 & 72 & 72 & 72 & 72 & 42 & 41 \\
\hline 3000 & 180 & 72 & 72 & 72 & 72 & 43 & 42 \\
\hline 3000 & 210 & 72 & 72 & 72 & 72 & 44 & 43 \\
\hline 5000 & 30 & 65 & 65 & 65 & 65 & 37 & 36 \\
\hline 5000 & 60 & 65 & 65 & 65 & 65 & 38 & 37 \\
\hline 5000 & 90 & 65 & 65 & 65 & 65 & 39 & 38 \\
\hline 5000 & 120 & 65 & 65 & 65 & 65 & 40 & 39 \\
\hline 5000 & 150 & 65 & 65 & 65 & 65 & 41 & 40 \\
\hline 5000 & 180 & 65 & 65 & 65 & 65 & 42 & 41 \\
\hline 5000 & 210 & 65 & 65 & 65 & 65 & 43 & 42 \\
\hline 7000 & 30 & 57 & 57 & 57 & 57 & 36 & 35 \\
\hline 7000 & 60 & 57 & 57 & 57 & 57 & 37 & 34 \\
\hline 7000 & 90 & 57 & 57 & 57 & 57 & 38 & 36 \\
\hline 7000 & 120 & 57 & 57 & 57 & 57 & 39 & 37 \\
\hline 7000 & 150 & 57 & 57 & 57 & 57 & 40 & 38 \\
\hline 7000 & 180 & 57 & 57 & 57 & 57 & 41 & 39 \\
\hline 7000 & 210 & 57 & 57 & 57 & 57 & 41 & 39 \\
\hline 9000 & 30 & 53 & 53 & 53 & 53 & 35 & 34 \\
\hline 9000 & 60 & 53 & 53 & 53 & 53 & 36 & 35 \\
\hline 9000 & 90 & 53 & 53 & 53 & 53 & 37 & 36 \\
\hline 9000 & 120 & 53 & 53 & 53 & 53 & 38 & 37 \\
\hline 9000 & 150 & 53 & 53 & 53 & 53 & 39 & 38 \\
\hline 9000 & 180 & 53 & 53 & 53 & 53 & 40 & 39 \\
\hline 9000 & 210 & 53 & 53 & 53 & 53 & 41 & 40 \\
\hline
\end{tabular}




\begin{tabular}{|c|c|c|c|c|c|}
\hline \multirow{2}{*}{ Bahan Bakar } & \multicolumn{5}{|c|}{ Pemakaian bahan bakar saat proses pengering } \\
\hline & 30 & 60 & 9 & 120 & 150 \\
\hline \multirow[t]{7}{*}{ LPG $(3 \mathrm{Kg})$} & $0,28 \mathrm{Kg}$ & $0,56 \mathrm{Kg}$ & 0,84 & $1,12 \mathrm{Kg}$ & $1,40 \mathrm{Kg}$ \\
\hline & & TABLE IV. & \multicolumn{3}{|c|}{ Penurunan Massa Pakaian } \\
\hline & & \multicolumn{2}{|c|}{$\begin{array}{c}\text { Kecepatan Putaran } \\
\text { Blower (Rpm) }\end{array}$} & \multicolumn{2}{|c|}{$\begin{array}{c}\text { Penurunan Tiap } 30 \text { Menit } \\
\text { (gram) }\end{array}$} \\
\hline & & \multicolumn{2}{|l|}{3000} & \multicolumn{2}{|c|}{445} \\
\hline & & \multicolumn{2}{|l|}{5000} & \multicolumn{2}{|c|}{405} \\
\hline & & \multicolumn{2}{|l|}{7000} & \multicolumn{2}{|c|}{320} \\
\hline & & \multicolumn{2}{|l|}{9000} & \multicolumn{2}{|c|}{250} \\
\hline
\end{tabular}

\section{KESIMPULAN}

Dari penelitian yang telah dilakukan didapatkan hasil dari penggunaan energy yang telah terpakai sebesar $1,96 \mathrm{Kg}$ dengan kapasitas pakaian $8 \mathrm{Kg}$ kemudian dimasukkan ke mesin cuci menghasilkan berat sekitar $4 \mathrm{Kg}$ kemudian dimasukkan ke ruang pengering menghasilkan waktu pengeringan 210 menit dengan hasil pakaian kering.

Dari hasil yang diperoleh bahwa energi yang berguna dengan hasil terbesar terjadi pada kecepatan putaran blower 9000 Rpm yaitu $10112798 \mathrm{~J} / \mathrm{s}$. Sedangkan hasil terkecil energy panas yang berguna terjadi pada kecepatan putaran blower $3000 \mathrm{Rpm}$ yaitu $6741865 \mathrm{~J} / \mathrm{s}$. Faktor yang mempengaruhi adalah kecepatan putaran blower. Perbedaan kecepatan putaran blower mempengaruhi hasil Temperatur panas masuk dan keluar. Selisih tempertaur panas masuk pada kecepatan putaran blower $3000 \mathrm{Rpm}$ yaitu $368^{\circ} \mathrm{K}$ dan temperature panas keluar yaitu $348{ }^{\circ} \mathrm{K}$. sedangkan Temperatur panas pada kecepatan putaran blower 9000 mempunyai selisih lebih besar $30^{\circ} \mathrm{K}$.

Dari penelitian yang dialakukan menunjukkan bahwa Efisiensi terbesar pada alat pemanas dengan kecepatan putaran blower yaitu pada $9000 \mathrm{Rpm}$ yaitu 11,05\% dan efisensi terkecil pada $3000 \mathrm{Rpm}$ yaitu 7,67 \%. Faktor efisiensi terbesar dipengaruhi oleh kecepatan putaran blower yang tinggi sehingga Temperatur panas yang dihasilkan pada alat pemanas mempunyai selisih cukup besar.

Dari penelitian yang telah dilakukan menunjukkan energy yang terpakai didalam ruang pengering pada kecepatan putaran blower $3000 \mathrm{Rpm}$ yaitu 7471135 J. dan kecepatan putaran blower $9000 \mathrm{Rpm}$ yaitu 4197267 J. Faktor yang mempengaruhi besar kecilnya energi yang terpakai adalah energi yang masuk ke lemari pemanas, karena pada kecepatan putaran blower $3000 \mathrm{Rpm}$ udara panas yang dihasilkan cenderung panas yang dihasilkan lebih banyak dari pada udaranya. Namun pada kecepatan putaran blower $9000 \mathrm{Rpm}$ cenderung udara yang dihasilkan lebih banyak dari pada panasnya.

Dari penelitian yang telah dilakukan efisiensi pada ruang pengering yang terbesar pada kecepatan putaran blower 3000 Rpm sebesar 6,42 \% dan efisiensi terkecil pada kecepatan putaran blower $9000 \mathrm{Rpm}$ sebesar 0,38.Factor yang mempengaruhi nilai efisiensi pada alat pengering pakaian adalah kecepatan putaran blower dan Temperatur panas masuk yang didapatkan. Jadi pada kecepatan putaran blower yang kecil didapatkan panas besar untuk mengeringkan pakaian.

\section{DAFTAR PUSTAKA}

[1] Kurniawan, M. A., \& Tjahjadi, G. (2016). PENGAMAN OTOMATIS KOMPOR GAS LPG SATU TUNGKU BERBASIS MIKROKONTROLER. 14, 19-34.

[2] Kusbandono, W., \& Untuk, C. (2015). Mesin Pengering Pakaian Energi Listrik Dengan. Snttm Xiv, 7-8.

[3] Mesin, J. T., Industri, F. T., Teknologi, I., \& Nopember, S. (2006). Pengaruh Posisi Difuser dan Variasi Kecepatan Udara Masuk terhadap Distribusi Temperatur Ruang Terkondisi Sebuah Studi Numerik. Jurnal Teknik Mesin, 8(1), 1-7. https://doi.org/10.9744/jtm.8.1.pp.1-7 
[4] Novita, D. M., \& Damanhuri, E. (2009). Perhitungan Nilai Kalor Berdasarkan Komposisi dan Karakteristik Sampah Perkotaan di Indonesia dalam Konsep Waste To Energy. Jurnal Teknik Lingkungan, 16(2), 103-114. https://doi.org/http://dx.doi.org/10.5614\%2Fjtl.2010.16.2.1

[5] kreith Frank, Prijono Arko., Prinsip - prinsip perpindahan panas., 1994, Penerbit Erlangga.Setyo Muji, Waluyo Budi, P. Candra Bagio, Munahar Suroto, Setyawan Chandra .I , K. W. Djoko, Efek Perubahan Komposisi LPG Terhadap Energy Delivery Pada Spark Ignition, www.researchgate.nate, ISSN 2407-9189, 2017, Universitas Muhammadiyah Magelang, di akses pada 10:00 WIB, 9 Maret 2020.

[6] Sukardi Chandrasa, Bendatu Monika, Laras, Pramesta Arie., Termodinamika Dasar Mesin Konversi Energi. , 2014, Universitas Mercubuana, ANDI. 